\title{
Attitudes, Motivations and Beliefs about L2 Reading in the Filipino Secondary School Classroom: A Mixed-methods Study
}

\author{
Andrzej Cirocki (Corresponding author) \\ Department of Education, University of York, York YO10 5DD, UK \\ E-mail: andrzej.cirocki@york.ac.uk \\ Jonel Caparoso \\ Banlag Integrated School, Banlag Valencia City, Bukidnon, 0709, Philippines \\ E-mail: jl.caparoso@yahoo.com
}

Received: 11-08-2016

Published: 10-12-2016
Accepted: 02-10-2016

doi:10.7575/aiac.ijalel.v.5n.7p.1
Advance Access Published: November 2016

URL: http://dx.doi.org/10.7575/aiac.ijalel.v.5n.7p.1

\begin{abstract}
This study is a two-part investigation. The first part focuses on ESL learners' attitudes and motivations for reading in the target language. The second part deals with ESL teachers' beliefs about motivating L2 learners to read. The study involved 100 ESL learners $(N=100)$ and 30 teachers $(N=30)$ from rural schools in Mindanao, the Philippines. All the participants were recruited through convenience sampling. In other words, participants were selected based on their convenient accessibility and proximity. The current study is a mixed-methods project. Both quantitative and qualitative methods were employed to collect different types of data. The instruments used were: a L2 reading attitude survey, a questionnaire dealing with motivations for L2 reading, a survey on beliefs about motivating L2 learners to read in English, a semi-structured interview and a L2-reading-lesson observation. The quantitative data were statistically analysed. Whenever appropriate, the data were presented in tables and on graphs. The qualitative data were analysed through thematic coding and used to support the quantitative data. The findings show that students have both positive and negative attitudes towards various aspects of $\mathrm{L} 2$ reading. They also have different levels of motivation for reading in English, with female participants having higher scores than male participants. The teachers, on the other hand, hold diverse beliefs about motivating learners to read in English. No significant correlation was found between teacher beliefs and students' motivations for reading in English. After the findings have been described, implications for teacher education and instructional practice are offered.
\end{abstract}

Keywords: Learner attitudes, Reading motivation, Teacher beliefs, Second language reading

\section{Introduction}

For the last several years there has been an ongoing discussion concerning the learning and teaching of reading skills in a second language (L2). Both processes have been described as difficult tasks. Despite much headway, there are still many people in the world that struggle with L2 reading. Today, ESL (English as a Second Language) learners are expected to read large numbers of print and digital texts for different purposes. Modern reading pedagogies provide learners with tasks meant to demonstrate analytical processing skills, critical thinking skills and problem solving ability. Teachers wishing to offer interesting reading experiences in the classroom should keep in mind that learning to read is highly dependent upon student attitudes and motivations. At the same time, ESL teachers should also be aware that their own beliefs about the reading process and how it should be taught easily influence student attitudes and motivations for L2 reading.

With this in mind, the current article will begin by discussing three important factors that affect L2 reading. An empirical study on attitudes, motivations and beliefs about ESL reading in the Mindanao context will then be presented. Once various methodological issues of this project have been discussed, data analysis and discussion will follow. The article will conclude with various implications for ESL teacher education and reading instruction.

\section{Attitudes, Motivations and Beliefs about L2 Reading}

Reading in a second language is a highly complex process. The successful development of reading skills depends on a number of factors, including the choice of texts, reading ability, prior knowledge of the topics of the selected texts, reasons for reading, text organisation and comprehension strategies. This article, however, will be limited to the following three factors: learner attitudes, learner motivations and teacher beliefs. The latter construct more often than not influences the former two. Consequently, the discussion will now be divided into three sections. The first will focus on learner attitudes towards L2 reading, the second will discuss L2 learner reading motivation and the third will look at teacher beliefs about motivating learners to read in the ELT context. 


\subsection{Learner Attitudes towards L2 Reading}

Attitude plays a vital role in a learner's development of reading skills. Firstly, learner attitudes influence the reading performance of L2 readers (Kush, Marley, \& Brookhart, 2005). For example, attitude influences the degree of a reader's engagement in the reading process as well as the amount of practice L2 readers undertake. Secondly, poor attitude often leads to situations in which learners read less, or completely avoid reading in the second language (McKenna, Stratton, Grindler, \& Jenkins, 1995).

Reading attitude also plays a vital role in the learning process. Involved are affective, behavioural and cognitive components. The first is nothing less than learner feelings about L2 reading (e.g., I'm not fond of reading in English.). The behavioural component is related to how L2 readers' attitudes influence their actions (e.g., I will avoid reading texts written in English.), whereas the cognitive component is linked to language learners' knowledge or beliefs about L2 reading (e.g., I believe L2 reading is difficult.). To make things more complex, the literature categorises reading attitudes into subtypes according to interests. For example, there is a general attitude towards reading. There are also specific attitudes towards reading about particular topics. As a result, teachers can encounter students who are fond of reading, but may hate Agatha Christie's texts.

There is an interesting body of research on attitudes towards L2 reading. For example, McGlinn and Parrish (2002, p. 185) observed "a profound change in their [participants'] reading habits and attitudes". The most significant changes in reading attitudes, however, as the above-mentioned researchers further pointed out, were evident in those students who improved their reading levels most. It is worth mentioning that this project involved ten ESL fourth and fifth graders. The increased attitudes towards L2 reading were documented through anecdotal records.

In another study, Yamashita (2013) investigated Japanese undergraduate students' attitudes towards reading in English as a Foreign Language (EFL). In the course of a 15-week reading programme, a number of attitudinal variables (e.g., comfort, intellectual value, anxiety, practical value) were investigated. There were no increases in comfort and intellectual value variables, but there was a decrease in anxiety. No effect on practical value was observed.

Aunario (2004) and Orencia (2006) conducted two projects related to reading attitudes of students in the Philippines. The former researcher reported significant differences in reading attitudes among primary school students. These differences were observed between younger and older students, male and female participants as well as high- and lowachievers. The second study, on the other hand, focused on the effects of a literature-based reading programme on L2 young learners' reading comprehension and attitudes towards reading. The results showed that the programme had a positive effect on both constructs under investigation. Learner attitudes improved markedly due to a positive classroom climate, attractive texts, diverse and stimulating activities and systematic reading.

There have been many interesting studies done on reading attitudes, but it is impossible to present them all. Six important findings from reading attitude research have been chosen to conclude this section. They are: (1) reading attitudes worsen over time (McKenna, 2001; McKenna \& Stahl, 2009), (2) reading attitudes worsen more quickly for poor readers (Richards \& Bear, 1986), (3) the number of reading interests declines with age (McKenna \& Stahl, 2009), (4) female students seem to possess more positive reading attitudes than male students (Anastasiadou, 2009; Ünal, 2010), (5) instructional methods can positively affect reading attitudes (Cirocki, 2008) and (6) learner experience in L1 reading has an impact on learner reading attitude in L2 (Lukhele, 2013).

\subsection{L2 Learner Reading Motivation}

As the foregoing discussion shows, reading attitudes influence the actions and behaviours of L2 learners. Thus, motivation to read is affected. In other words, learners' motivation directs their reading activity, determining the amount of input they are exposed to, the level of engagement with the content and the quality of response to the text.

Motivation is an abstract and multifaceted construct that is employed to clarify why humans think and behave as they do (Dörnyei, 2001). Motivation pertains to "the choices individuals make about which activity to do or not to do, their degree of persistence at the chosen activities, and the amount of effort they put forth to do the activity" (Wigfield, 2000, pp. 140-141). Motivation dictates why people choose to do a particular thing, how long they engage in the activity and how hard they intend to undertake it (Dörnyei, 2001).

There are many theories concerning motivation (Dörnyei \& Ushioda, 2013). The following discussion, however, will be guided by Baker and Wigfield's (1999) approach to reading motivation. This approach takes into account the engagement perspective and the achievement motivation theory. According to the first position, engaged $\mathrm{L} 2$ readers are "motivated to read for different purposes, utilize knowledge gained from previous experience to generate new understandings, and participate in meaningful social interactions around reading" (Baker \& Wigfield, 1999, p. 452). The second perspective combines, among other things, efficacy beliefs (i.e., confidence about one's capability to produce the desired level of performance), intrinsic and extrinsic types of motivation, and purposes for achievement. The last construct is essential in situations where L2 learners have to decide, for example, which of the available reading tasks to do or how much effort needs to be invested in each task (Wigfield, Eccles, \& Rodriguez, 1998). Motivated readers are engaged in reading, have a positive attitude towards reading, reflect on the value and importance of reading, use numerous strategies for a broad range of reading experiences, show a preference for challenge in reading and have high self-efficacy (Berkeley, Mastropieri, \& Scruggs, 2011; Gambrell, 2011; Guthrie, Van Meter, McCann, Wigfield, Bennett, Poundstone, Rice, Faibisch, Hunt, \& Mitchell, 1996).

As can be observed, motivation plays an important role in reading development. Reading for internal reasons dictates the amount students read and predicts reading achievement (Guthrie, 2008; Guthrie, Coddington, \& Wigfield, 2009). Student interest in the material is related to the proper application of effective learning strategies, resulting in a quicker comprehension of reading materials. It is likely that readers who find their material interesting are more motivated to 
utilise the cognitive processes crucial for good comprehension (Guthrie, 2008). In this vein, since much of learning in schools requires reading, engagement in reading will reflect engagement in learning. The processes that generally boost motivation may promote favourable attitudes as well as engagement in reading (Cambria \& Guthrie, 2010).

Human personal cognitions and emotions are to a large extent socially constructed. It is difficult to separate the social from the personal types of motivation, crucial to L2 reading (Dörnyei, 2001). It may be said that social motivation deals with becoming productive members of society. The social type also deals with achievement at school so as to be accepted by peers and teachers. The personal type refers to satisfying personal desires and gaining knowledge. The satisfaction allows readers to fulfil their curiosity while becoming more educated (Dörnyei 2001; Urdan \& Maehr, 1995). In addition, the social type of motivation is definitely influenced by a reader's social environment. The reader's parents, teachers, peer group and school, more often than not, make up the reader's social environment.

Reading motivation has been widely researched in the ELT context. For example, an interesting qualitative case study involving a South Korean student of English was recently conducted by Ro (2013). The researcher wanted to find out whether extensive reading can motivate an unmotivated reader. As a result, she measured motivation through three selfreported questionnaires, three interviews and observations of twenty-four extensive reading sessions over an 8-week period. The results disclosed that extensive reading had a positive effect on the participant and considerably enhanced her motivation to read in English. What contributed to the participant's increased motivation was that it "can be done alone at any place conveniently, unlike other English studies. I can do it at any place I want such as at my favourite café. I don't need help from other people; you just need your book and time. It's as simple as that” (Ro, 2013, p. 226). The other two contributing factors included satisfaction and usefulness. The participant gained satisfaction every time she finished reading a book. This, in turn, encouraged her to read more and also motivated her to become a faster and better reader. She also understood that the whole reading experience was useful as it increased her overall L2 proficiency.

In another study, in Pakistan, Khan (2016a) investigated the L2 reading motivation of thirty graduates. In this project, the data were collected through a questionnaire in a learning environment where students used WhatsApp for their academic development. The findings of this project revealed that the use of WhatsApp motivated the participants to read in English. The teachers and school authorities, however, disapproved of WhatsApp. They considered it ineffective and believed it to be a source of distraction in the reading classroom.

Khan (2016b) also investigated the levels of instrumental and integrative motivation for L2 reading in Pakistan. He gathered his data through an adapted version of Dörnyei's language-learning-motivation questionnaire, which he distributed among forty male pre-university students. The findings indicated that participants had high levels of instrumental motivation for reading English. Instrumental motivation was mainly used to read in English to achieve a special goal, for example, to get a degree or scholarship (Item 9). Good employment turned out to be the strongest instrumental motivation (Item 1, 2, and 4) in this cohort. Regarding the integrative motivation for L2 reading, the study revealed that the participants were motivated to read in English to deepen their knowledge about literature, the arts and culture (Items 4, 1, 10). They were also motivated to read in the target language to become part of the English-reading community (Item 2).

Sani, Chik, Nik and Raslee (2011) investigated L2 reading motivation and academic reading strategies. More specifically, the study aimed to look at the relationship between reading motivation and reading strategy use among Malaysian undergraduates. Both constructs were analysed in terms of gender. The researchers concluded that female participants were more motivated L2 readers than male participants, reading motivation was "moderate" and cognitive strategies were used over metacognitive ones.

The last two research projects to be described in this section were conducted in the Philippines. In the first project, Perez (2004) focused on the reading ability and motivation of secondary school students. A number of instruments were used to collect data. The findings revealed that there was a strong correlation between the five (out of six) analysed motivational factors and reading comprehension. In the second study, Mante-Estacio (2012) determined the relationship between a number of dimensions of reading motivation among Filipino bilingual students. The findings implied that the selection of reading material to be used in the classroom should take into account learner interests, preferences and familiarity with both the content and format of the reading material. The selected texts should pose a certain level of challenge to learners, yet should not lead to discouragement or L2 reading avoidance. Finally, a balance between "narrative and informational texts" should be promoted (Mante-Estacio, 2012, p. 25).

The preceding discussion reveals that motivation and the right attitude are fundamental for students to develop their reading skills, derive pleasure from reading and overcome various limitations. However, it is important to remember that both attitudes and motivations for reading are more often than not influenced by teacher beliefs about reading and the teaching philosophy employed by teachers. The issue of teacher beliefs is the focus of the next section.

\subsection{Teacher Beliefs about L2 Reading}

Teacher beliefs about teaching and learning perform a vital role in classroom processes. These beliefs underpin teacher decisions about classroom instruction concerning goals, procedures, methods, approaches, materials and management (Borg, 2008; Harste \& Burke, 1977; Richards \& Rodgers, 2001; Zheng, 2015). The teacher beliefs concept is not new, and has been referred to by different educators and educational philosophers in different ways. For example, Jackson (1968) used the notion of hidden curriculum, which is nothing less than understandings, premises and propositions that teachers acquire in the process of teaching. A few years later, Ainscough (1997) and Sendan and Roberts (1998) preferred to refer to teacher beliefs as private theories of teachers. More recently, teacher beliefs are used interchangeably with teacher cognitions (Borg 2008; Saito \& Van Poeteren 2012), teacher perceptions (Brown, 2009; Dippold, 2009), pedagogical beliefs (Borg, 2011) and teacher thinking (Johnson, 2009). 
No matter what terminology is employed to refer to teacher beliefs, there are two aspects that need to be clarified. Firstly, systems of beliefs are rarely well-structured. Some of the beliefs in those systems tend to be more central, and thus more difficult to change. Secondly, a clear distinction must be made between the notion of beliefs and the notion of knowledge. This distinction is not sufficiently emphasised in the literature, and therefore those two notions happen to be wrongly equated. Knowledge rests on a truth condition, whereas beliefs do not depend upon it (Richardson, 2003). As Richardson (2003, p. 3) further explains, "beliefs are propositions that are accepted as true by the individual holding the belief, but they do not require epistemic warrant".

There are a number of empirical studies that deal with teacher beliefs. Some of them investigate teacher beliefs about various aspects of form-focused instruction, including grammar, vocabulary and pronunciation (Farrell \& Lim, 2005; Gerami \& Noordin, 2013). Others investigate teacher beliefs about teaching language skills (Graham, Santos, \& Francis-Brophy, 2014; Yang \& Gao, 2013). There are research projects that report strong relationships between teacher beliefs and reading instruction (Farrell \& Ives, 2015; Kuzborska, 2011). There are also studies showing that there is a somewhat limited correspondence between the two (Farrell \& Lim, 2005). For this reason, more research is required in this area.

\section{Methodology}

The empirical part of this article presents a small-scale study that was conducted in Mindanao, the Philippines, with ESL secondary school students and teachers. This project investigated three research questions. The first two questions focus on ESL students: (1) What are the attitudes of Filipino ESL students towards reading in English as a second language? and (2) What different aspects of reading motivation can be identified among Filipino ESL students? The literature review emphasised that L2 learner attitudes and motivations are affected by teacher beliefs. Thus, the third research question was: What beliefs about L2 reading motivation and L2 reading instruction do Filipino ESL teachers hold?

To collect reliable and extensive data to answer these three research questions, a mixed-methods approach was employed. The combination of quantitative and qualitative methods was to ensure not only a better understanding of the studied phenomena, but also to give the entire project a higher credibility. The quantitative data underwent statistical analysis, whereas the qualitative data were analysed through thematic coding. This method "identif[ies], analys[es] and report[s] patterns (themes) within data" (Braun \& Clarke, 2006, p. 79).

\subsection{Participants}

The research population consisted of Filipino ESL students $(N=100)$ and teachers $(N=30)$. The student group consisted of both male $(n=43)$ and female $(n=57)$ participants. The student-participants were 8th graders from a number of rural secondary schools in Mindanao. A considerable number of the participants came from poor indigenous families. These were families that made their living from farming and housekeeping. The parents were very often uneducated and unable to help with schoolwork. The majority of the participants were neither critical readers nor autonomous learners. In many cases, their teachers described them as struggling readers who were not keen on reading English texts. The first languages of the participants included: Cebuano, Ilonggo, Matigsalug, Ilocano and Maguindanao.

In the teacher group, there were also male $(n=9)$ and female $(n=21)$ participants. Ages ranged from 24 to 53 , with the average being 33. The participants worked full-time for Mindanao secondary schools in rural areas. The majority had been teaching English for 11 to 15 years. Their teaching qualifications were as follows: $\mathrm{PhD}(n=1), \mathrm{MA}(n=21)$ and $\mathrm{BA}$ $(n=8)$.

Convenience sampling was used to select participants for this project. This means that the participants were chosen on the basis of availability (Weathington, Cunningham, \& Pittenger, 2010).

\subsection{Instruments and Procedure}

In the present project, five instruments were used to collect the data: a L2 reading attitude survey, a questionnaire dealing with motivations for L2 reading, a survey on beliefs about motivating learners to read in the target language, a semi-structured interview and L2-reading-lesson observation. The first three instruments were used in the quantitative part. They are briefly described below.

At the outset, attitudes were measured through a survey made up of twenty statements. The participants $(N=100)$ were asked to respond as "Strongly Agree" to "Strongly Disagree", using the five-point Likert scale.

Next, motivations for reading were estimated using a 50-item questionnaire. This instrument was a slightly modified version of the Motivations for Reading Questionnaire designed by Wigfield and Guthrie (1997). All the statements on the 5-point Likert scale were closed-ended. The statements reflected the following eleven constructs of reading motivation: reading efficacy, reading challenge, reading curiosity, reading involvement, importance of reading, reading work avoidance, competition in reading, recognition for reading, reading for grades, social reasons for reading and compliance. More specifically, reading efficacy, reading challenge and reading work avoidance were included in the Competence and Efficacy Beliefs group. Reading curiosity, reading involvement, importance of reading, competition in reading, recognition for reading and reading for grades formed the Goals for Reading group. The last group, Social Purposes of Reading, consisted of social reasons for reading and compliance. This detailed scale was used to encourage participants $(N=100)$ to accurately describe the concept of reading motivation. The participants could then specify the intensity of the individual constructs of the concept.

Finally, beliefs were measured using a 37-item survey on teacher beliefs about motivating L2 learners to read. The 5point Likert scale, slightly adapted from Quirk, Unrau, Ragusa, Rueda, Lim, Velasco, Fujii, Bowers, Nemerouf and Loera's (2010) study, was purposely chosen since it closely correlated with the student scale on reading motivations. 
Because of the close correlation, the results of these two instruments could be easily compared. It was hoped that the comparison could be used to reveal the teachers' and the students' perceptions on L2 reading motivation and how these perceptions affected the teaching-learning process in the Filipino rural secondary school. The survey was completed by thirty participants $(N=30)$.

Once all the quantitative instruments had been collected, they underwent statistical analysis. Descriptive statistics were calculated and the various results between male and female groups of participants were compared using a student's ttest. A correlation analysis, using Pearson's correlation coefficient, was carried out to determine the relationship between teacher beliefs about motivating ESL learners to read and student motivations for L2 reading. The level of significance selected for this study was $\mathrm{p}<0.05$, whereas highly significant differences were observed when $\mathrm{p}<0.01$. Whenever appropriate, the results were presented in tables and on charts.

In the qualitative part, twenty semi-structured interviews with students and twenty lesson observations followed by post-observation conversations with ESL teachers were employed. The interview was based on six open-ended questions. Open-ended questions were deliberately used as they allowed participants to supply detailed answers to the presented questions, and allowed participants to clarify their responses (Mackey \& Gass, 2005). Another reason for using open-ended questions was that they offered participants the possibility of giving unlimited answers, thereby providing additional information on the thinking processes, creativity and resourcefulness of the participants.

The purpose of the observations with post-observation conversations was twofold. They aimed to "reconstruct the events of the [reading lesson] so that deeper meanings and insights [could] be gleaned from the observation" (Zepeda, 2015 , p. 55). Another reason was to collect further data related to the previously posed research questions. These postobservation conversations were nothing less than "collaborative critical thinking process[es] involving cognitive and affective interactions between [the participants and the researcher] who explore their experiences in order to reach new intersubjective understandings [of the observed phenomena]" (Yukawa, 2006, p. 206). Altogether, twenty participants $(n=20)$ agreed to be observed and take part in the post-observation conversations.

As soon as the interview and lesson observation with post-observation conversations came to an end, the textual data underwent qualitative analysis. The textual data were reviewed and label-based codes were developed. Finally, themes were identified, analysed and discussed.

\subsection{Limitations}

In this section, the shortcomings of the study are addressed. The first limitation was that the research population was rather small; it consisted of only 130 participants. Quantitative measures require large populations to be regarded as representations of groups of subjects to whom research outcomes can be transferred (Mackey \& Gass, 2005). The second limitation was that only a few secondary schools were involved in this project. In the future, it would be good to select a larger number of schools and involve schools from all the regions of Mindanao. Furthermore, some of the instruments were used with a small number of participants (e.g., lesson observations). Finally, a thorough analysis of documents such as course descriptions and syllabi would have strengthened the discussion. Such an analysis could then give the researchers license to expect that Filipino teachers know how to successfully teach L2 reading.

\subsection{Ethical Considerations}

The study was conducted in accordance with the ethical standards promoted by the American Educational Research Association (2011) and the British Education Research Association (2011). The informed consent of all the participants was requested prior to the study. The rights and dignity of the participants were respected at all stages of the research project. Any information that could reveal the identity of the participants was deliberately excluded.

Additionally, several aspects needed to be taken into consideration. Firstly, the school principals and superintendents were contacted to obtain permission to do research in the selected schools. The school principals and superintendents were given a detailed summary of the study and encouraged to ask questions about the project. Additional documents required by the Philippine system were submitted by the researchers so that the project was regarded as formal and legal. Secondly, all the schools involved in this project were visited by the Filipino researcher in advance. He briefed all the participants about the project and collected their consent forms. Finally, since the research population consisted of Filipino citizens only, the Filipino researcher assumed the role of a community leader whose responsibility was to act as a consultant throughout the research process.

\section{Data Analysis}

The purpose of this section is to analyse the gathered data. For the sake of clarity, the analysis is presented in three sections related to the research questions listed above. The sections focus on: (1) attitudes of Filipino students towards L2 reading, (2) different aspects of Filipino students' L2 reading motivation and (3) Filipino teacher beliefs about motivating L2 learners to read in English.

\subsection{Attitudes of Filipino Students towards L2 Reading}

Filipino students' attitudes were measured using a 20 -item survey. The items were arranged from the lowest (i.e., highest disagreement) to the highest (i.e., highest agreement) score (see Table 1). The five items with the highest disagreement were: I enjoy discussing texts with friends outside school (item 9; M=-0.30), Reading is boring (item 15, $M=-0.20$ ), I enjoy discussing texts with classmates in the classroom (item 8; M=-0.10), I like reading poems (item 7; $M=-0.04$ ) and I prefer reading books to watching $T V$ (item $11 ; M=0.01$ ). In contrast, the five items with the highest agreement included: Reading in English is important (item 1; $M=1.63$ ), I practise reading in English to get a better job in the future (item 19; M=1.27), I prefer texts with pictures to plain texts (item 12; M=1.14), I prefer silent reading to reading aloud (item 13; $M=0.87$ ) and Reading is difficult (item 16; $M=0.61$ ). 
Table 1. Filipino Students' Attitudes towards L2 Reading

\begin{tabular}{ccllr}
\hline No & Item & \multicolumn{1}{c}{ Attitudes } & Mean (M) \\
\hline 1. & 9. & I enjoy discussing texts with friends outside school. & -0.30 \\
\hline 2. & 15. & Reading is boring. & -0.20 \\
\hline 3. & 8. & I enjoy discussing texts with classmates in the classroom. & -0.10 \\
\hline 4. & 7. & I like reading poems. & -0.04 \\
\hline 5. & 11. & I prefer reading books to watching TV. & 0.01 \\
\hline 6. & 10. & I prefer print texts to digital texts. & 0.04 \\
\hline 7. & 3. & I should be regularly given reading tests. & 0.10 \\
\hline 8. & 14. & Reading is enjoyable. & 0.21 \\
\hline 9. & 18. & I would be a better reader if I were more encouraged by my teacher. & 0.24 \\
\hline 10. & 20. & I like receiving books as gifts. & 0.25 \\
\hline 11. & 6. & I like reading comic books. & 0.32 \\
\hline 12. & 5. & I like reading magazines and newspapers. & 0.33 \\
\hline 13. & 17. & I feel upset when I have to read books for school. & 0.37 \\
\hline 14. & 2. & I should be regularly given reading homework. & 0.53 \\
\hline 15. & 4. & I like reading short stories. & 0.54 \\
\hline 16. & 16. & Reading is difficult. & 0.61 \\
\hline 17. & 13. & I prefer silent reading to reading aloud. & 0.87 \\
\hline 18. & 12. & I prefer texts with pictures to plain texts. & 1.14 \\
\hline 19. & 19. & I practise reading in English to get a better job in the future. & 1.27 \\
\hline 20. & 1. & Reading in English is important. & 1.63 \\
\hline & & &
\end{tabular}

Male and female participants made different choices to the twenty items presented above (see Table 2 and Figure 1). In the male group, the arrangement of the items, from the lowest (i.e., highest disagreement) to the highest (i.e., highest agreement) score, included: I enjoy discussing texts with friends outside school (item 9; M=-1.14), I like receiving books as gifts (item 20; $M=-0.56$ ), I like reading poems (item 7; M=-0.51), I should be regularly given reading tests (item 3; $M=-0.37), I$ enjoy discussing texts with classmates in the classroom (item 8; M=-0.28), I prefer reading books to watching TV (item 11; M=-0.28), I like reading short stories (item 4; $M=-0.16$ ), I prefer print texts to digital texts (item 10; $M=-0.14$ ), Reading is boring (item 15; $M=-0.12$ ), Reading is enjoyable (item 14; $M=-0,09$ ), I prefer silent reading to reading aloud (item 13; $M=0$ ), I should be regularly given reading homework (item $2 ; M=0.05$ ), I like reading magazines and newspapers (item 5; M=0.3), I would be a better reader if I were more encouraged by my teacher (item 18; $M=0.72$ ), I feel upset when I have to read books for school (item 17; M=0.81), Reading is difficult (item 16; $M=0.86$ ), I like reading comic books (item 6; $M=0.98$ ), I prefer texts with pictures to plain texts (item 12; $M=1.37$ ), Reading in English is important (item 1; M=1.42) and I practise reading in English to get a better job in the future (item 19; $M=1.53$ ).

Table 2. Attitudes towards L2 Reading: Male and Female Preferences

\begin{tabular}{|c|c|c|c|c|}
\hline No & Item & Attitudes & $\begin{array}{c}\mathrm{M} \\
\text { male }\end{array}$ & $\begin{array}{c}\mathrm{M} \\
\text { female }\end{array}$ \\
\hline \multirow[t]{2}{*}{1.} & 9 & I enjoy discussing texts with friends outside school. & -1.14 & \\
\hline & 15 & Reading is boring. & & -0.26 \\
\hline \multirow[t]{2}{*}{2.} & 20 & I like receiving books as gifts. & -0.56 & \\
\hline & 6 & I like reading comic books. & & -0.18 \\
\hline \multirow[t]{2}{*}{3.} & 7 & I like reading poems. & -0.51 & \\
\hline & 18 & I would a better reader if I were more encouraged by my teacher. & & -0.12 \\
\hline \multirow[t]{2}{*}{4.} & 3 & I should be regularly given reading tests. & -0.37 & \\
\hline & 8 & I enjoy discussing texts with classmates in the classroom. & & 0.04 \\
\hline \multirow[t]{2}{*}{5.} & 8 & I enjoy discussing texts with classmates in the classroom. & -0.28 & \\
\hline & 17 & I feel upset when I have to read books for school. & & 0.04 \\
\hline \multirow[t]{2}{*}{6.} & 11 & I prefer reading books to watching TV. & -0.28 & \\
\hline & 10 & I prefer print texts to digital texts. & & 0.18 \\
\hline \multirow[t]{2}{*}{7.} & 4 & I like reading short stories. & -0.16 & \\
\hline & 11 & I prefer reading books to watching TV. & & 0.23 \\
\hline \multirow[t]{2}{*}{8.} & 10 & I prefer print texts to digital texts. & -0.14 & \\
\hline & 7 & I like reading poems. & & 0.32 \\
\hline
\end{tabular}




\begin{tabular}{|c|c|c|c|c|}
\hline \multirow[t]{2}{*}{9.} & 15 & Reading is boring. & -0.12 & \\
\hline & 9 & I enjoy discussing texts with friends outside school. & & 0.33 \\
\hline \multirow[t]{2}{*}{10.} & 14 & Reading is enjoyable. & -0.09 & \\
\hline & 5 & I like reading magazines and newspapers. & & 0.35 \\
\hline \multirow[t]{2}{*}{11.} & 13 & I prefer silent reading to reading aloud. & 0 & \\
\hline & 16 & Reading is difficult. & & 0.42 \\
\hline \multirow[t]{2}{*}{12.} & 2 & I should be regularly given reading homework. & 0.05 & \\
\hline & 14 & Reading is enjoyable. & & 0.44 \\
\hline \multirow[t]{2}{*}{13.} & 5 & I like reading magazines and newspapers. & 0.3 & \\
\hline & 3 & I should be regularly given reading tests. & & 0.46 \\
\hline \multirow[t]{2}{*}{14.} & 18 & I would a better reader if I were more encouraged by my teacher. & 0.72 & \\
\hline & 20 & I like receiving books as gifts. & & 0.86 \\
\hline \multirow[t]{2}{*}{15.} & 17 & I feel upset when I have to read books for school. & 0.81 & \\
\hline & 2 & I should be regularly given reading homework. & & 0.89 \\
\hline \multirow[t]{2}{*}{16.} & 16 & Reading is difficult. & 0.86 & \\
\hline & 12 & I prefer texts with pictures to plain texts. & & 0.96 \\
\hline \multirow[t]{2}{*}{17.} & 6 & I like reading comic books. & 0.98 & \\
\hline & 4 & I like reading short stories. & & 1.07 \\
\hline \multirow[t]{2}{*}{18.} & 12 & I prefer texts with pictures to plain texts. & 1.37 & \\
\hline & 19 & I practise reading in English to get a better job in the future. & & 1.07 \\
\hline \multirow[t]{2}{*}{19.} & 1 & Reading in English is important. & 1.42 & \\
\hline & 13 & I prefer silent reading to reading aloud. & & 1.53 \\
\hline \multirow[t]{2}{*}{20.} & 19 & I practise reading in English to get a better job in the future. & 1.53 & \\
\hline & 1 & Reading in English is important. & & 1.79 \\
\hline
\end{tabular}

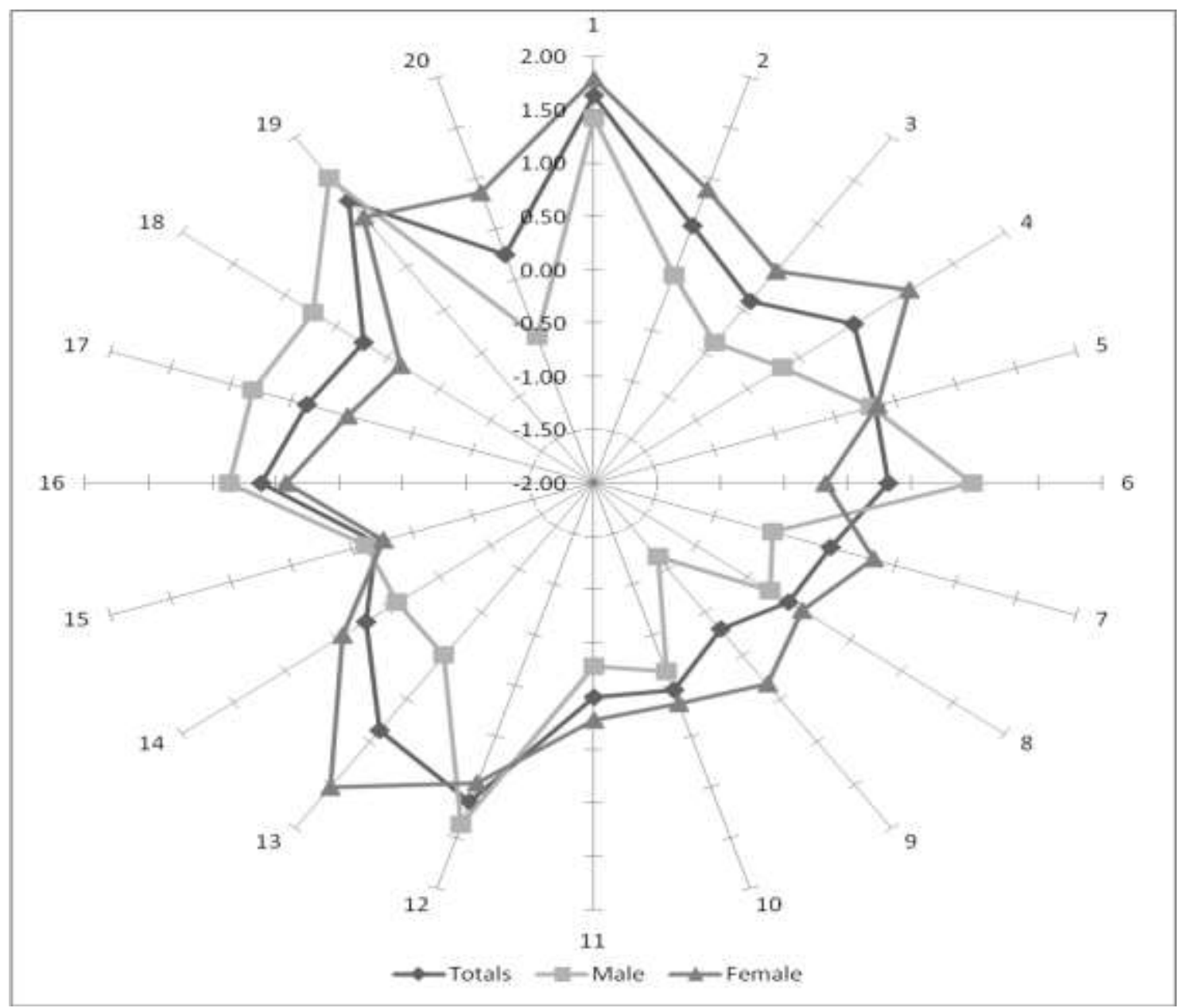

Figure 1. Attitudes towards L2 Reading: Male and Female Preferences

In the female group the distribution of the chosen items was different. Starting with the lowest mean score items, the sequence was as follows: Reading is boring (item 15; M=-0.26), I like reading comic books (item 6; $M=-0.18$ ), I would be a better reader if I were more encouraged by my teacher (item 18; M=-0.12), I enjoy discussing texts with classmates in the classroom (item 8; M=0.04), I feel upset when I have to read books for school (item 17; M=0.04), I prefer print texts to digital texts (item $10 ; M=0.18$ ), I prefer reading books to watching TV (item $11 ; M=0.23$ ), I like reading poems (item 7; M=0.32), I enjoy discussing texts with friends outside school (item 9; $M=0.33$ ), I like reading magazines and 
newspapers (item 5; $M=0.35$ ), Reading is difficult (item 16; $M=0.42$ ), Reading is enjoyable (item 14; $M=0.44$ ), I should be regularly given reading tests (item 3; $M=0.46$ ), I like receiving books as gifts (item 20; $M=0.86$ ), I should be regularly given reading homework (item $2 ; M=0.89$ ), I prefer texts with pictures to plain texts (item 12; M=0.96), I like reading short stories (item 4; $M=1.07$ ), I practise reading in English to get a better job in the future (item 19; M=1.07), I prefer silent reading to reading aloud (item 13; M=1.53) and Reading in English is important (item 1; M=1.79).

There were significant differences among the items selected in these two groups of participants. For example, in items 2 $(t=-4.45, d f=98, p=<0.0001), 3(t=-3.92, d f=98, p=0.0002), 4(t=-4.7, d f=98, p=<0.0001), 6(t=4.45, d f=98, p=<0.0001)$, $9(t=-6.71, d f=98, p=<0.0001), 13 \quad(t=-6.49, d f=98, p=<0.0001), 17 \quad(t=3.02, d f=98, p=0.0032), 18 \quad(t=3.27, d f=98$, $p=0.0015)$ and $20(t=-5.13, d f=98, p=<0.0001)$, the differences were highly significant. Significant differences between the groups concerned were also observed in items $1(t=-2.59, d f=98, p=0.0112), 7(t=-3.1, d f=98, p=0.0026), 12(t=2.03$, $d f=98, p=0.0456), 14(t=-2.32, d f=98, p=0.0223)$ and $19(t=2.35, d f=98, p=0.0208)$. No significant differences between male and female participants were found in the remaining six items. These were: $5(t=-0.21, d f=98, p=0.8361), 8(t=-$ 1.3, $d f=98, p=0.1953), 10(t=-1.2, d f=98, p=0.2311), 11(t=-1.83, d f=98, p=0.0704), 15(t=0.57, d f=98, p=0.5718)$ and $16(t=1.95, d f=98, p=0.0537)$.

To sum up the statistical analysis, it was found that in thirteen cases out of twenty, female participants achieved higher scores than male participants. What is more, in the case of the fourteen items with significant differences in scores, there were nine items in which female participants scored higher than male participants. These nine items were: Reading in English is important (item 1; M=1.79), I should be regularly given reading homework (item 2; M=0.89), I should be regularly given reading tests (item 3; $M=0.46$ ), I like reading short stories (item $4 ; M=1.07$ ), I like reading poems (item 7; M=0.32), I enjoy discussing texts with friends outside school (item 9; M=0.33), I prefer silent reading to reading aloud (item 13; $M=1.53$ ), Reading is enjoyable (item $14 ; M=0.44$ ) and I like receiving books as gifts (item 20; $M=0.86$ ).

The quantitative data will now be supported by qualitative ones gathered through interviews. At the interview stage, a number of participants stated that they are not fond of reading in English because they consider themselves to be "slow" (S3, S9) or "struggling" (S11, S 17) readers. Some participants mentioned that they are always nervous while reading in English because they: "cannot understand what [they are] reading about" (S3, S8, S10, S17), "fear being laughed at by classmates" (S3, S14, S17) or "do not know the meaning of many words in texts" (S2, S20). In addition, the majority of the participants find reading "tiring" (S1, S2, S5, S12) and "boring" (S3, S9, S11). Some even admitted that the very thought of reading texts for school makes them "upset" (S17) because the texts they are given to read are "hardly ever interesting" (S8, S10, S14, S19). When reading is boring, the participants look for more interesting activities. For example, two participants said that they "play with their mobile phones" (S8, S14) or another two "rest in bed" (S10, S19). However, there was a small number of participants who think reading is "enjoyable" (S4, S6, S15). They also felt that they "can learn many things through reading" (S6, S15). They emphasised, though, that they prefer to read short texts (S4, S15).

When it comes to reading assignments to be completed at home, the participants were evenly divided. The first group thought that reading homework is "a good idea" (S4, S6, S7, S15). The participants felt that through reading assignments they can: "learn what has to be learnt" (S4), "easily improve [their] reading comprehension" (S6, S15) and "land a good job like being a flight attendant" (S7). The second group, on the other hand, felt that homework is "not a wise idea" (S3, S9, S11, S17). The participants made it clear that they do not feel like doing any reading assignments after school because: "there are so many things to be done at home" (S11), "reading is tiring" (S12, S17), "reading is difficult and should be done with the teacher at school" (S3) and "time after school should be free from school activities" (S9, S11).

A considerable number of participants reported that reading is difficult. As a result, this issue was probed further. According to the participants, reading is difficult because: "the words in texts are new/unfamiliar" (S1, S2, S3, S12), "reading takes a lot of time" (S3, S9, S11, S17), "the texts are too long" (S1, S2, S3) and "the material is hard to understand" (S3, S17). Some participants also added that reading is difficult because, very often, they are "not sufficiently motivated to read (by teachers or parents)" (S1, S2, S10, S14). In addition, there are situations when the participants cannot "relate to the reading material" (S4, S6, S10) selected by the teacher.

Finally, when asked about their preferences for print or digital texts, a slightly bigger number of participants opted for digital texts. Digital texts, as the participants stated, are "nice" (S10, S14), "more motivating" (S2, S9), "more enjoyable" (S3, S9, S15) and "more convenient" (S6, S7). Those who prefer print texts mentioned that they are "more accessible" (S1, S8), "easier to read" (S6, S11, S20), "easier to understand" (S6, S11) and "less tiring" (S13, S15). Participants stated that print texts "stimulate the imagination more than digital texts" (S15). The participants prefer print text for two other reasons: "students can take notes on them" (S6, S11) and "students do not need to worry about technical issues such as a low battery" (S8, S20).

\subsection{Different Aspects of Filipino Students' L2 Reading Motivation}

Having analysed Filipino students' attitudes towards L2 reading, it is time to look at their reading motivation. A 50-item questionnaire with three main groups of motivations (see 3.2) was used. The scores were listed in ascending order. In the first group, Competence and Efficacy Beliefs, the scores were as follows: self-efficacy $(M=0.08)$, work avoidance $(M=0.23)$ and challenge $(M=0.4)$. In the second group, Goals for Reading, the lowest score was involvement $(M=0.1)$, followed by competition $(M=0.29)$, recognition $(M=0.39)$, grades $(M=0.47)$, curiosity $(M=0.77)$, and then importance $(M=1.08)$. In the last group, Social Purposes of Reading, social reasons for reading $(M=-0.48)$ came first and compliance $(M=0.30)$ came second. Given this evidence, it can be inferred that the participants were the least motivated 
to read for social purposes $(M=-0.12)$. Then, motivations related to competence and efficacy beliefs $(M=0.25)$ and goals for reading $(M=0.45)$ followed.

With regard to gender, the three main groups of motivations were ranked in the same way. The order, from the lowest to the highest scores, was as follows: (1) Social Purposes of Reading, (2) Competence and Efficacy Beliefs and (3) Goals for Reading. The scores in the male group included $M=-0.46, M=0.06$ and $M=0.17$, respectively. In the female group, the calculated means were: $M=0.13, M=0.4$ and $M=0.67$.

Despite the fact that the outcome of the ranking activity was the same in both groups of participants, the intensity of motivation observed in the three groups presented above was different (see Figure 2). For instance, in the Competence and Efficacy Beliefs group, male participants' scores were: self-efficacy $(M=-0.35)$, challenge $(M=-0.01)$ and work avoidance $(M=0.42)$, whereas female participants' scores were: work avoidance $(M=0.09)$, self-efficacy $(M=0.40)$ and challenge $(M=0.71)$. In the second group, Goals for Reading, the calculated means in the male cohort were: involvement $(M=-0.27)$, competition $(M=-0.03)$, recognition $(M=0.2)$, curiosity $(M=0.29)$, grades $(M=0.41)$ and importance $(M=1.02)$. Female participants, on the other hand, chose: involvement $(M=0.37)$, grades $(M=0.52)$, recognition $(M=0.53)$, competition $(M=0.53)$, importance $(M=1.11)$ and curiosity $(M=1.13)$. In the last group, Social Purposes of Reading, the calculated means in both male and female groups were: $M=-1.05$ (social) and $M=0.26$ (compliance), and $M=-0.05$ (social) and $M=0.33$ (compliance), respectively.

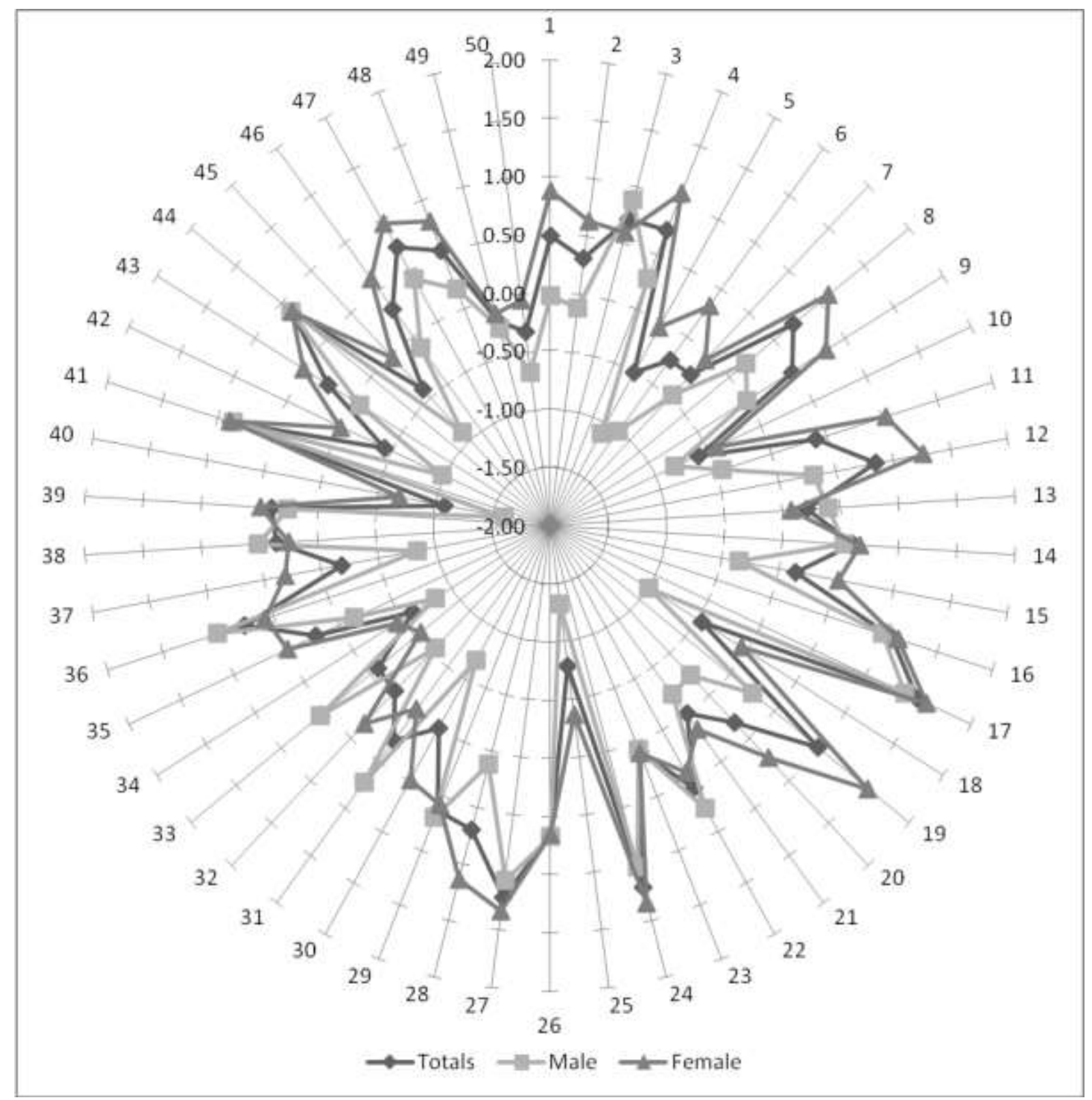

Figure 2. Intensity of Motivation with Regard to Student Gender

The analysis above indicated that there were significant differences in six scores in male and female groups. More precisely, in these six cases: self-efficacy, challenge, curiosity, involvement, competition and social reasons for reading, there were four scores where the difference was described as highly significant. These items included: self-efficacy ( $t=-$ 3.16, $d f=98, p=0.0021)$, challenge $(t=-2.71, d f=98, p=0.0079)$, curiosity $(t=-3.64, d f=98, p=0.0004)$ and social reasons for reading $(t=-3.99, d f=98, p=0.0001)$. No significant differences were found for work avoidance $(t=1.27, d f=98$, 
$p=0.2063)$, importance $(t=-0.45, d f=98, p=0.6571)$, recognition $(t=-1.24, d f=98, p=0.2175)$, grades $(t=-0.4, d f=98$, $p=0.6927)$ and compliance $(t=-0.24, d f=98, p=0.8098)$. Regarding the three main groups of motivations, the statistical analysis revealed that there were no significant differences between male and female participants' scores for Competence and Efficacy Beliefs ( $t=-1.3, d f=98, p=0.1978)$ and Goals for Reading $(t=-1.87, d f=98, p=0.0643)$. However, a significant difference was found in the Social Purposes of Reading ( $t=-2.07, d f=98, p=0.0409)$. It should be noted that in all the significant cases pertaining to L2 reading motivation, the higher scores concerned female participants.

Further analysis, using qualitative data from interviews, disclosed that many of the participants describe themselves as "moderately motivated to L2 reading" (S2, S8, S20). There was also a substantial number of students who consider themselves "unmotivated" (S3, S11). In general, the participants concluded that they would be better L2 readers if their teachers encouraged them more (S11, S12, S17). In particular, they think it would be a good idea if teachers "provided interesting texts to read" (S3, S9, S15), "taught reading with fun" (S2, S9, S20), "did not limit reading classes only to text comprehension" (S6, S8, S20), "let [students] choose books to read, at least from time to time" (S1, S4, S13), "promoted reading through the use of technology" (S10, S14), "divided long texts into parts" (S3, S9, S11), "used audio books, or combined reading with watching films" (S9, S10), "prepared group quizzes to check comprehension or response to texts" (S2, S20) and "accepted more than just one interpretation" (S1, S2, S19, S20).

\subsection{Filipino Teacher Beliefs about Motivating L2 Learners to Read in English}

The present study also focused on teacher beliefs about motivating L2 learners to read in the target language. The purpose of this section is twofold: to present Filipino teachers' perspective on L2 reading motivation and, together with the student perspective (see 4.2), to offer a fuller picture of the construct under study in the Mindanao context. The data analysed below had been gathered through a survey and through lesson observations.

The questionnaire consisted of forty-seven statements (see Figure 3). They were divided into the following ten themebased clusters: self-efficacy, challenge, curiosity, involvement, importance, grades, competition, social reasons for reading, compliance and autonomy support. As the statistical analysis showed, teacher beliefs varied in strength. The sequence from the least to the most represented beliefs was: competition $(M=0.17)$, autonomy support $(M=0.56)$, grades $(M=0.67)$, importance $(M=0.82)$, social aspects $(M=0.83)$, involvement $(M=0.84)$, challenge $(M=0.88)$, curiosity $(M=0.95)$, self-efficacy $(M=1.53)$ and compliance $(M=1.67)$.

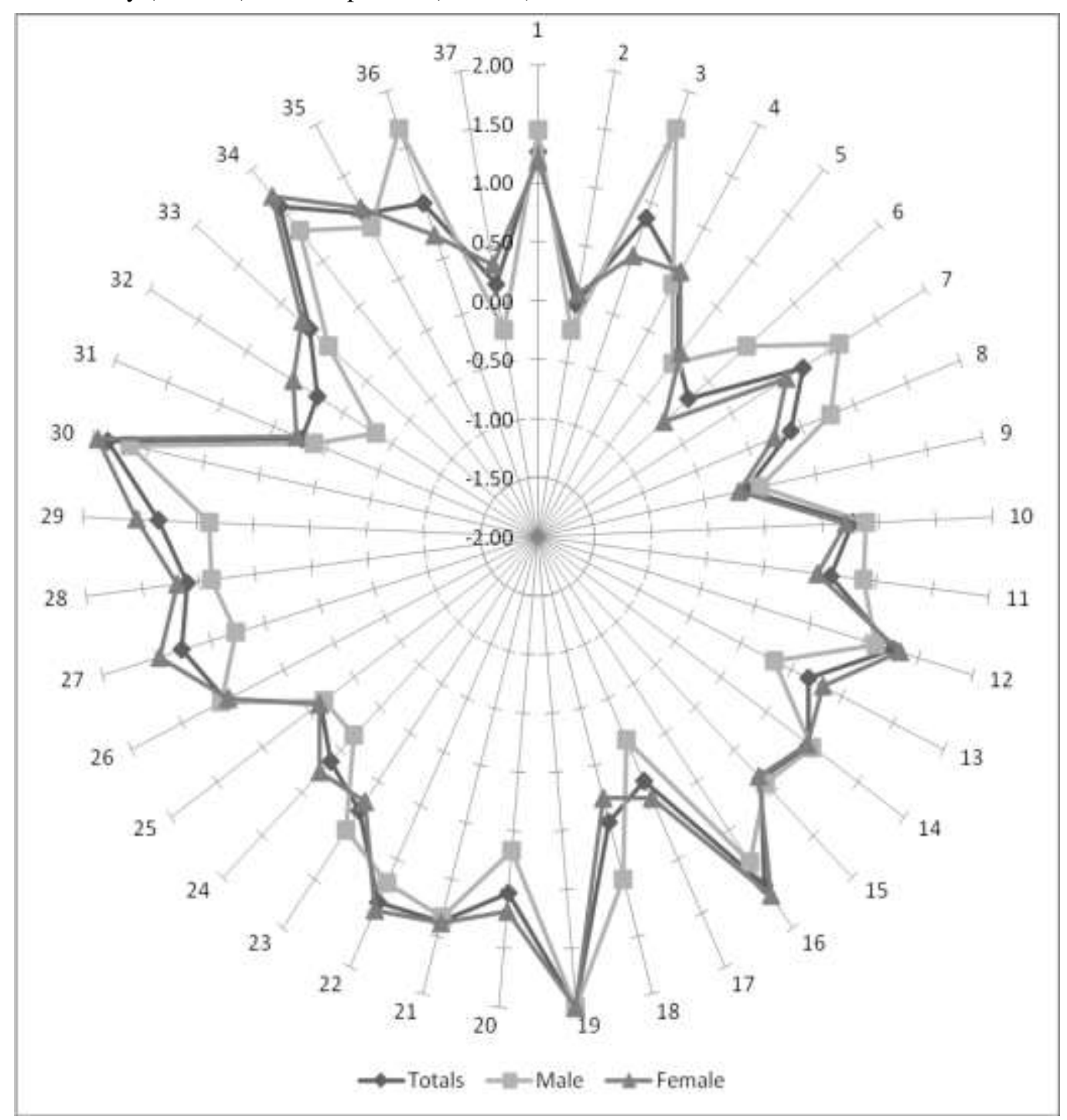

Figure 3. Teacher Beliefs about Motivating ESL Learners to Read 
The sequence of these clusters was different for male and female teachers. For instance, in the male group, the strength of the individual clusters was ranked as follows: competition $(M=0.18)$, autonomy support $(M=0.43)$, social reasons for reading $(M=0.5)$, importance $(M=0.72)$, curiosity $(M=0.76)$, challenge $(M=0.78)$, involvement $(M=0.85)$, grades $(M=1.18)$, self-efficacy $(M=1.44)$ and compliance $(M=1.44)$. By contrast, female teachers ranked their beliefs differently. The sequence starting from the weakest clusters was: competition $(M=0.16)$, grades $(M=0.45)$, autonomy support $(M=0.61)$, involvement $(M=0.84)$, importance $(M=0.86)$, challenge $(M=0.92)$, social reasons for reading $(M=0.98)$, curiosity $(M=1.03)$, self-efficacy $(M=1.56)$ and compliance $(M=1.76)$. Despite the fact that the order of the clusters was different in both groups, there were no significant differences $(p>0.05)$ in the choices male and female teachers made.

It should also be clarified that these nine clusters of beliefs: self-efficacy, challenge, curiosity, involvement, importance, grades, competition, social reasons for reading and compliance corresponded to the student motivations discussed above (see 4.2). The relation between these nine aspects in teacher and student groups was analysed, yet no significant correlation $(p>0.05)$ was found.

The preceding analysis will now be supported by qualitative data gathered through the post-observation conversations. The purpose of using qualitative data is to describe in greater depth the objective analysis presented above.

All the observed teachers made it clear that their students are important to them. As a result, the participants teach as best as they can so that their "students can become better readers" (T1, T3, T6). The participants want their students to realise that they can "learn many things through reading" (T6, T16) and that "reading can be a pleasurable activity" (T12, T23). Some of the teachers mentioned that reading is a big problem for their students. They also complained that some students are unconcerned about what happens in the classroom, and therefore often come unprepared. For instance, two teachers stated that:

\section{A couple of students in my class are not interested in learning at all. They are always late and never do their reading homework. (T4)}

I have a student who never does any reading. He does not even bring his textbook to the class. He could not care less. (T8)

The teachers generally thought they provide their students with interesting texts, yet the teachers never formally checked to see whether the students felt that the texts were interesting. The texts were selected according to teachers' own tastes, "making sure different topics were covered in different texts" (T6, T12, T26). The fact that different topics are covered in reading lessons was confirmed in the observed lessons. However, not all lessons showed that students find these topics engaging. In fact, there were some texts to which students found it difficult to relate or had limited prior knowledge. The post-reading questions hardly ever exploited the texts used. In the majority of cases, the questions focused either on checking the understanding of new vocabulary or testing whether students remembered small things, both of which contributed very little to the global understanding of the texts the students were working on. When asked about the purpose of doing such activities, some of the teachers explained that they want to "challenge students" (T8, T24) or "give students opportunities to learn difficult things through reading" (T9, T11).

According to the observations, there were few very engaging lessons that promoted collaboration in reading and used fun, competitive, engaging activities to teach reading skills. In general, the teachers stated that providing such engaging lessons require "a lot of preparation" (T10, T11, T16), and "teachers do not have much time because of the paper work involved in their everyday jobs" (T19). Some teachers also pointed out that such classes require "interesting materials, but their libraries are extremely limited in resources, not to mention recently published materials" (T6, T8, T25).

All the participants considered reading to be a very important component of their teaching. To prepare students for future life, many of them believed that being "demanding" (T6, T8) and "giving students many reading tests" (T11, T29) is the best thing to do. They stated that "students' reading development is fostered through grades" (T5, T9, T13), so "the more grades, the better" (T13). Some of them also added that "grades are the best reflection of how good the students are at reading" (T9, T13, T22).

The observations further disclosed that ESL classes are conducted in a very student-friendly atmosphere. The classes tend to be slightly teacher-centred. As a result, learner autonomy is not regularly promoted. The lessons revealed that the teacher's interpretation of the texts is always the best option. Unfortunately, students were not encouraged to ask questions after reading. In the majority of the observed lessons, the students answered comprehension questions. Some teacher-participants pointed out that they "do not have time in which students could ask questions about the text being discussed" (T28) or "do not invite students to ask questions about the text being discussed as students hardly ever know what questions to ask, so it would be a waste of time" (T14). The observation also showed that the questions used in the classroom tend to fall into three categories: factual, cause/effect and inference. Finally, a few teacher-participants thought that there is "no need to explain to students why particular texts are discussed or some reading strategies introduced" (T7, T17) in the classroom.

\section{Data Discussion}

The purpose of this section is to discuss the empirical findings of this study. For the sake of clarity, the discussion, following the structure of the data analysis, is presented in three sections. The focus of these sections is as follows: (1) Filipino student attitudes towards L2 reading (2) Filipino student L2 reading motivation and (3) Filipino teacher beliefs about motivating ESL learners to read in the target language. 


\subsection{Filipino Student Attitudes towards L2 Reading}

The present study revealed that Filipino students have some positive and some negative attitudes towards reading in English. It was also found that these attitudes vary between male and female students. The observed patterns showed that the majority of Filipino students $(n=87 ; 87 \%)$ consider reading to be an important part of learning English as a second language. This is a very positive observation, especially when confronted with Orencia's remark: "(...) Filipinos are not a reading populace. [The consumption of books, newspapers and other publications] is way [behind] their East Asian neighbors" (Orencia, 2006, p. 3). Many participants thought that by being fluent or successful readers they will be more employable $(n=59 ; 59 \%)$. This way of thinking may be related to the new $\mathrm{K}-12$ Curriculum recently introduced in the Philippines. One of the purposes of introducing new standards to the K-12 Curriculum is to prepare students for the rigour and demands of the current workforce. Reading skills are particularly emphasised. The document reads: "Learners learn about language and how to use it effectively through their engagement with and study of texts" ( $K$ to 12 English Curriculum Guide, 2013, p. 4).

To become a fluent reader, a lot of practice is required. In the studied cohort, however, not all participants were interested in practising reading skills systematically. For example, 20 percent of the participants $(n=20)$ thought reading homework was not a good idea and 21 percent $(n=21)$ were undecided about it. The first group was mainly represented by male participants $(n=19 ; 19 \%)$. Some of their various reasons for disliking this idea were: lack of time, lack of interest or level of difficulty. The undecided group, however, consisted mainly of female participants $(n=15 ; 15 \%)$.

As can be seen, the participants seem to resonate Heafner and Spooner's (2008) observations. The participants in the current study do not like homework because they find it too challenging, time-consuming or are simply not interested in it. All these reasons were also shared by students in a study by Landing-Corretjer (2015). The participants, in her study, further explained that they find it difficult to concentrate at home and other after-school commitments prevent them from doing their homework. The present study, however, does not seem to be in agreement with Olson's (2008) observation that students often adopt a cover and do not admit why they do not do homework. In our study, the Filipino participants turned out to be very open about their attitudes towards homework assignments and provided concrete reasons why they behaved in particular situations as they did.

Not being particularly fond of reading homework assignments, a substantial number of the participants $(n=57,57 \%)$ like the issue of being given regular reading skills tests. These tests, as some participants mentioned during the interview stage, "would force them to read more and more, and more and more carefully" (S4, S7), "would make the students better readers" (S6) and "would make reading itself less difficult, because practice makes perfect" (S8, S15). The idea of the regular reading skills tests can be related to the concept of formative assessment of reading skills whose goal is to both inform and individualise instruction according to students' progress in attaining the aims of the reading programme. As Afflerbach, Kim, Crasses and Cho (2011) point out, this type of assessment does not focus only on reading comprehension, though many teachers think it does. This type of assessment is also meant to prioritise the use of the information students acquire from texts to perform reading-related tasks. Ideally, both receptive and productive skills are integrated.

By combining receptive and productive skills, student ability to interact is increased. As a result, students not only receive input in the classroom, but also actively construct new meanings. The purpose of such complex tasks should be carefully explained to students. As the current study showed, the participants dislike discussing texts with classmates in the classroom $(n=48 ; 48 \%)$ or with friends outside school $(n=54 ; 54 \%)$. Students must be made aware that reading is social in nature, hence the need for tasks that involve such social aspects as: (1) open discussions, in which students converse directly with each other to uncover the meanings of text, (2) student-led discussion groups that allow individuals to interact with each other relatively freely, (3) collaborative reasoning that enables students to benefit from each other's thinking and perspectives, (4) arranging partnerships that can help to build a social scaffold for reading, (5) socially constructing the management that enhances students' sense of belonging to the school culture, and (6) scaffolding social motivations over time to enable adolescents to internalize the social goals and patterns of education (Antonio \& Guthrie, 2008, p. 50).

As the current study further showed, the participants consider reading to be enjoyable as well as difficult, tiring and boring. Positive attitudes were expressed by a large number of female participants who described many of the provided texts as "very interesting" (S) and "fascinating" (S). This finding may be related to recent studies that confirm that female students are better readers than male students (Merisuo-Storm \& Soininen, 2012; Stevens, 2011). Regarding the negative attitudes towards L2 reading, both male and female participants described the reading activity as "difficult" (S1, S2) because of new vocabulary, "tiring" (S2, S12) because of the length of texts and "boring" (S3, S11) because of unappealing topics.

To eliminate negative attitudes in the classroom, it is vital that teachers select appropriate reading materials. Such materials should be both appealing and engaging to students. What is more, whenever possible, they should be recommended by the students themselves. These materials do not need to be limited to print books, long stories or famous poems. As the data indicated, these materials could include newspaper/magazine extracts, digital texts or short multimodal texts. The latter group would be welcome in the Philippine context. As this study showed, the participants enjoy reading newspapers and magazines $(n=58 ; 58 \%)$, digital texts $(n=49 ; 49 \%)$ and prefer multimodal texts $(n=80$; $80 \%$ ). These findings correspond to another study in which male students clarified that their outside-school reading involves media, video games, television, Internet sites and sport magazines (Merisuo-Storm \& Soininem, 2012).

Consequently, it is essential that reading engagement is fostered among students, for it:

(...) not only involves (...) positive attitudes to reading, it also includes the commitment and perseverance that committed readers mobilize in order to read challenging or complex texts necessary 
to obtain a personal advantage or a specific goal, (...). Furthermore, it is essential for the maintenance

and further development of reading skills beyond school (Roe, 2016, p. 86).

\subsection{Filipino Student L2 Reading Motivation}

The second construct investigated in this study was L2 reading motivation. Motivation and attitudes towards reading are closely related. They can be regarded as two different ways of illustrating why people read. The present study revealed that the participants had different levels of motivation for reading in English. Some of the participants were more motivated, some less motivated and there was a group of unmotivated readers. The general tendency, though, was that female participants were more motivated to read in English than male participants.

Following the analysis above, the most common reading goals were: importance, curiosity and grades. For instance, all the participants indicated that they read because it is important for them to be good readers. This observation reflects what Roe (2016, p. 93) heard from her participants when she asked them why it is important to be good readers. The response was: "Because you have to, you read all the time, it is something you need out there (...) you have to be able to read and understand what you read (...)".

Some participants also opted for curiosity as a goal for L2 reading. The participants admitted reading to get information about new things $(n=89 ; 89 \%)$ or broaden their knowledge about things they are interested in $(n=82 ; 82 \%)$. Curiosity is a vital construct in reading, and therefore should be systematically nurtured in the classroom. By engaging their curiosity, students explore texts at various levels. This helps them to become active readers. They first question, respond and interact critically and creatively with authors' ideas. They then make meaning from the texts (Cirocki, 2016).

Grades appear to be another goal students set for reading. As the participants stated, grades reflect how well they are doing in L2 reading $(n=76 ; 76 \%)$. Despite the fact that students read for grades, teachers should be cautious about awarding grades for the sake of motivating students. This may lead to students attaching more significance to grades than to the reading material. In the long run, this may lead to a decline in intrinsic motivation in those students (Martinez, 2010).

According to Woolfolk and Margetts (2013), grades may not be used as motivators with all students. Low grades may discourage some students enough that they give up reading. For example, research suggests that grades may cause more harm than good for low-achieving students (Kaplan, Peck, \& Kaplan, 1997). Likewise, low grades may affect student self-esteem and cause a decline in motivation (Kaplan, Peck, \& Kaplan, 1997). For this reason, teachers should keep in mind that "rewards are effective only if [students are] interested enough to work towards receiving them" (Marshall, 2012). Bruner (1961, p.14) in turn emphasises that "interest in the material to be learned is the best stimulus to learning, [not] such external goals as grades or later competitive advantage".

Regarding competence and efficacy beliefs, the current project indicated that a number of female participants ( $n=38$; $38 \%$ ) enjoy challenging reading. In particular, they like when texts make them think. Challenging texts are very important in the reading journey of every student. Confident and enthusiastic readers derive pleasure from mastering unknown vocabulary and complicated ideas included in texts that present a challenge. This is in agreement with Csikszentmihalyi and Csikszentmihalyi (1988). According to these two researchers, reading that is intrinsically motivating requires a challenge that corresponds to a reader's current skills. They further add that readers derive pleasure from the reading activity when this balance occurs. It can be inferred that a "preference for challenge is indicative of intrinsic motivation" (Wigfield \& Tonks, 2010, p. 254).

The study also identified a group of participants that avoids the challenges involved in reading. This group consisted of both male and female students. They dislike difficult vocabulary in texts or stories with too many characters. Similar avoidance factors are provided by Pressley and Allington (2015). Work avoidance is nothing less than a negative motivation to read. L2 readers with work-avoidance goals do not put much effort into reading (Anderson Swan, 2003; Nicholls \& Miller, 1984). To remedy such a situation, appropriate strategies are required. For example, students could be involved in collaborative reading tasks in the classroom. Such tasks involve not only reading, but also analysing, discussing and responding to texts through various modes (Cirocki, 2016; O'Donnell-Allen, 2006).

L2 reading self-efficacy, or in other words, readers' conviction of their ability to read in English, was also looked at in this project. It turned out that quite a substantial number of the participants have low reading self-efficacy. For example, they do not consider themselves to be good readers $(n=29 ; 29 \%)$ and they do not think they will do well in reading in the next semester $(n=38 ; 38 \%)$. As the data revealed, male participants have lower self-efficacy than female participants. This is in agreement with research conducted by Mills, Pajares and Herron (2006) and Henry (2009). In both studies, the researchers found that female students have higher self-efficacy beliefs than their male counterparts. Mills, Pajares and Herron (2006) also investigated the relationship between self-efficacy and anxiety. They found that learners with low reading self-efficacy suffer more from anxiety. Anxiety, in turn, may exert a negative impact on their self-efficacy. Other studies show that readers with high self-efficacy not only employ more reading comprehension strategies (Li \& Wang, 2010; Naseri \& Zaferanieh, 2012), but work harder and persist longer when dealing with reading challenges as opposed to those who lack confidence in their own potential (Liao, 2009, cited in Su \& Wang, 2012).

Finally, the data disclosed that the participants are not motivated to read for social purposes. The majority of the participants seem to be involved in reading because they have to. They may have demanding teachers who require that they $(n=56 ; 56 \%)$ finish their reading on time, so they do their reading work exactly as their teachers want it $(n=65$; $65 \%$ ). The social reasons for reading, in contrast to compliance, received a very low score. This type of motivation deals with sharing the meanings gained from reading. As this study revealed, the participants hardly ever talk to their families about the books they read $(n=62 ; 62 \%)$. Neither do they read books to their parents $(n=86 ; 86 \%)$ or siblings 
$(n=76 ; 76 \%)$. Given this evidence, it may be inferred that there is a clear link between this observation and the participants' attitudes towards discussing texts with classmates.

Parents act as a supportive affective family climate and as highly motivated role models. They shape L2 readers' motivation and attitudes by developmentally appropriate timing of achievement pressure as well as instilling reading confidence (Eccles, Wigfield, \& Schiefele, 1998). Apart from demonstrating that they are readers themselves, parents could share books with their children, respond to children's questions, help children with reading assignments, offer paired reading sessions and discuss texts as well as reading challenges. Existing research widely suggests that family involvement has impact on both reading development and literacy performance (August \& Shanahan, 2008; DudleyMarling, 2009; Ediger, 2008; Ordones-Jasis \& Ortis, 2006).

On the other hand, it is vital that teachers provide $\mathrm{L} 2$ reading mentoring, guidance and support. Motivation and attitudes of L2 readers are affected by such features as their teacher's empathy, competence, warmth, immediacy, active motivational socialising behaviour (e.g., task presentations, feedback) and classroom management (Dörnyei, 2001). Group motivation has an impact on the interpersonal processes of student behaviour within learner groups. The emphasis is on peer pressure. Group structure, the developmental level (e.g. degree of maturity) and a teacher's leadership style and behaviour (Ehrman \& Dörnyei, 1998) are all intertwined. Readers are also influenced by school motivation, which can be analysed in such terms as stress placed on accomplishment, general expectations regarding student potential and evaluation practices (Maehr \& Midgley, 1991).

\subsection{Filipino Teacher Beliefs about Motivating L2 Learners to Read in English}

The last aspect to be discussed is teacher beliefs about motivating learners to read in a second language. It is important to see what beliefs Filipino teachers hold, to what extent these beliefs are reflected in their teaching practice and how these beliefs correspond to L2 learners' motivation for reading.

The project revealed that the teacher-participants seem to be serious about teaching reading skills. The teachers tried hard to create a positive atmosphere in the classroom and to help their students to succeed. As the analysis above showed, all the participants felt it is important that students improve their reading skills in the classroom, have positive feelings about themselves as L2 readers and have positive feelings about their reading progress. It should be borne in mind that teachers from rural areas face various hardships in their everyday jobs. According to the interview records, for example, both teachers and students sometimes have to cover quite long distances to get to schools. The mixedability classes are crowded with students of different ages, who have different first languages, and different attitudes and motivations for learning. The school libraries lack materials. Many students come from poor families and cannot afford to buy textbooks.

Despite the many difficulties, the participants seem to be enthusiastic about their jobs, and as Fried (1995) argued "drawn to the dilemmas and potentials of the young people who come into class every day". Some also possess the characteristics listed by Hayes (2002). The characteristics include: taking a forthright attitude, being focused, showing concern for students, being enthusiastic about their work, being courteous, extending the professional role and showing appreciation.

The participants challenge their students in the classroom. As the observations indicated, the reading material is sometimes too difficult in terms of vocabulary or content, which was pointed out by the student-participants themselves (see 4.1). However, to respond to the criticism, the teacher-participants stated that "It is vital for students to be given challenging material so that they can use the strategies they leant to comprehend the text on their own". This corresponds to Blackburn's (2013) observation with which we concur. Students should not be provided with texts that are "completely above their heads" (2013, p.127). It is essential to challenge students in the classroom, yet appropriate instruction and the right level of scaffolding must be provided (Cirocki, 2016).

The participants believe that it is vital that students read about a wide variety of topics. They also think that students should be given interesting texts to read. The teachers reported that they take student interests into account while selecting texts for their students' lessons. This is in agreement with Zimmerman and Schunk (2011). Interesting texts exert a strong influence on student intrinsic motivation, which enhances student engagement. However, the analysis of the gathered data showed that there is a discrepancy between what Filipino teachers and students reported. According to many students, texts tend to be boring, thus making reading tiring and wasteful.

It should be emphasised that texts must match student interests. The reading activity students undertake, either in the classroom or at home, must be a purposeful one (Cremin, Mottram, \& Collins, 2014; Koda, 2005). For this reason, it is very important that teachers set meaningful purposes for reading. This aspect of reading instruction is often neglected. Teachers more often than not set trivial reasons for reading (Fisher, Bates, Gurvitz, 2014), which is not sufficient to stimulate student engagement. This has also been observed in the current study. To turn students into engaged readers, relevant reasons as well as interesting texts must be provided (Fisher, Bates, Gurvitz, 2014). As Cremin, Mottram and Collins (2014, p. 6) further point out, " (...) reading is related to the human need to make sense of the world, the desire to understand, to make things work and to make connections". This is what makes it purposeful in nature.

As with the student opinions, the teachers considered grades to be a very good motivator and an accurate reflection of student abilities. Given this evidence, it may be inferred that student motivation for reading may have been influenced by the teacher-participants' beliefs. A big disappointment was that the teacher-participants do not promote learner autonomy. In other words, they do not aim to produce independent - lifelong - readers. As the collected data indicated, the participants do not encourage students to generate questions with regard to texts they discuss. Creative thinking is not promoted. For example, many of the teachers thought that there is only one proper interpretation of a text. This corresponds to what the student-participants reported that the teacher's interpretation is always the best. 
Finally, although the observed lessons were interesting in many ways, the lack of current trends in teaching reading was visible. The post-observation conversations revealed that reading classes tend to focus mainly on comprehension. While teachers admit to promoting reading strategies, the discussions disclosed that incorporating metacognitive strategies into reading instruction needs closer attention. Likewise, complex tasks to thoroughly exploit texts and cooperative reading are required. According to van Haren and Vervoorn (2012), cooperative reading not only promotes sustained reading engagement and motivation, but it also develops autonomous readers and makes students members of a reading community. Last but not least, reading instruction in the Mindanao rural schools needs to be regularly negotiated with students, just like classroom reality that is constructed through the social interactions of both teachers and students (Cirocki, 2016).

\section{Conclusion and Implications for $L 2$ Teacher Education and Reading Instruction}

This article investigates Filipino student attitudes and motivations for L2 reading as well as Filipino teacher beliefs about motivating L2 learners to read in English. The findings of the study revealed that male and female students have different attitudes and motivations for L2 reading. More interestingly, the statistical analyses of the gathered data indicated that female students tended to obtain higher scores than male students. The study also showed that Filipino teachers hold various beliefs about motivating L2 learners to read in English. While the analysed beliefs varied between male and female teachers, no significant differences were observed. Likewise, no significant correlation between teacher beliefs about motivating students and student motivations for L2 reading was found.

This study has important implications for ESL teacher education and L2 reading instruction in the Philippine context. Regarding teacher education or professional development courses, it is important that the notions of attitude and motivation, specifically in relation to L2 reading, are thoroughly explored. It would be useful if teachers were shown effective ways of shaping student attitudes, interests, engagement and motivation in the reading classroom. Another issue to be given close attention is remedial reading methods. It is necessary that teachers know how to provide direct assistance to struggling readers.

As far as L2 reading instruction is concerned, it is advisable that teachers use interesting texts and negotiate the list of texts with students. In this way, students will feel that their voice is taken into consideration. Student involvement in classroom decisions will also contribute to their autonomy. Additionally, it is important that texts are thoroughly exploited in the classroom. As a result, teachers are encouraged to widen their repertoire of text-related questions and promote opinion, interpretation, and personalised and speculative questions. Students should also be invited to ask different types of questions to demonstrate both critical and creative thinking skills. Finally, it is vital that teachers use reading tasks that promote real life communication, fun, creativity, collaboration, personal response to texts as well as diverse topics and media. Such activities will not only engage students in the complex process of reading, but will also make them excited about reading.

\section{References}

Afflerbach, P., Kim, J-Y., Crasses, M. E., \& Cho, B-Y. (2011). Best practices in literacy assessment. In L. M. Morrow \& L. B. Gambrell (Eds.), Best practices in literacy instruction (4th ed.) (pp. 319-341). New York, NY: The Guilford Press.

Ainscough, V. (1997). Reflection in action: Increasing teacher awareness of the learning. System, 25, 571-579. American Educational Research Association. (2011). AERA Code of Ethics. Educational Researcher, 40(3), 145-156. Anastasiadou, S. D. (2009). Multivariate statistical analysis of Greek pupils' attitudes toward reading. International Journal of the Book, 6(1), 35-43.

Anderson Swan, E. (2003). Concept-oriented reading instruction: Engaging classrooms, lifelong readers. New York, NY: The Guilford Press.

Antonio, D., \& Guthrie, J. T. (2008). Reading is social: Bringing peer interaction to the text. In J. T. Guthrie (Ed.), Engaging adolescents in reading (pp. 49-63). Thousand Oaks, CA: Corwin Press.

August, D., \& Shanahan, T. (2008). Intro and methodology. In D. August \& T. Shanahan (Eds.), Developing reading and writing in second-language learners: Lessons from the report of the national literacy panel on language-minority children and youth (pp. 1-18). New York, NY: Routledge, the Centre for Applied Linguistics, and the International Reading Association.

Aunario, J. (2004). Reading self-concept and intrinsic motivation in cooperative learning (Unpublished Master's dissertation). University of the Philippines, Diliman, Philippines.

Baker, L., \& Wigfield, A. (1999). Motivation for reading and their relations to reading activity and reading achievement. Reading Research Quarterly, 34, 452-477.

Berkeley, S., Mastropieri, M. A., \& Scruggs, T. E. (2011). Reading comprehension strategy instruction and attribution retraining for secondary students with learning and other mild disabilities. Journal of Learning Disabilities, 44(1), 1832.

Blackburn, B. R. (2013). Classroom motivation from A to Z: How to engage your students in learning. New York, NY: Routledge.

Borg, S. (2008). English language teachers' beliefs about research: Perspectives from the Netherlands. Journal of the Dutch Association of Modern Language Teachers, 9(3), 3-13.

Borg, S. (2011). The impact of in-service teacher education on language teachers' beliefs. System, 39, 370-380. 
Braun, V., \& Clarke, V. (2006). Using thematic analysis in psychology. Qualitative Research in Psychology, 3 (2), 77 101.

British Educational Research Association. (2011). Ethical guidelines for educational research. London: BERA.

Brown, A. (2009). Students' and teachers' perceptions of effective foreign language teaching: A comparison of ideals. The Modern Language Journal, 93, 46-60.

Bruner, J. S. (1961). The process of education. Cambridge, MA: Harvard University Press.

Cambria, J., \& Guthrie, J. T. (2010). Motivating and engaging students in reading. The NERA Journal, 46(1), 16-29.

Cirocki, A. (2008). Extensive reading approach to literature in the EFL secondary school classroom: A qualitative study (Unpublished doctoral thesis). Adam Mickiewicz University, Poznan, Poland.

Cirocki, A. (2016). Developing learner autonomy through tasks: Theory, research, practice. Halifax: LinguaBooks.

Cremin, T., Mottram, M., Collins, F. M., Powell, S., \& Safford, K. (2014). Building communities of engaged readers: Reading for pleasure. New York, NY: Routledge.

Csikszentmihalyi, M., \& Csikszentmihalyi, I. (1988). Optimal experience: Psychological studies of flow in consciousness. Cambridge: Cambridge University Press.

Department of Education $\mathrm{K}$ to 12. (2013). $K$ to 12 English curriculum guide. Retrieved from http://www.deped.gov.ph/sites/default/files/page/2015/English\%20CG\%20for\%20reuploading_03.04.15.pdf\#overlay-

context=k-to-12/About/curriculum-guides/Grade-1-10

Dippold, D. (2009). Peer feedback through blogs: Student and teacher perceptions in an advanced German class. ReCALL, 21(1), 18-36.

Dörnyei, Z. (2001). Teaching and researching motivation. London: Longman.

Dörnyei, Z., \& Ushioda, E. (2013). Teaching and researching motivation (2nd ed.). New York, NY: Routledge.

Dudley Marling, C. (2009). Home-school literacy connections: The perceptions of African American and immigrant ESL parents in two urban communities. Teachers College Record, 111(7), 1713-1752.

Eccles, J. S., Wigfield, A., \& Schiefele, U. (1998). Motivation. In N. Eisenberg (Ed.), Handbook of child psychology (5th ed., vol. 3, pp. 1017-1095). New York, NY: Wiley.

Ediger, M. (2008). Psychology of parental involvement in reading. Reading Improvement, 45, 46-52.

Ehrman, M. E., \& Dörnyei, Z. (1998). Interpersonal dynamics in second language education: The visible and invisible classroom. Thousand Oaks, CA: Sage.

Farrell, T. S. C., \& Ives, J. (2015). Exploring teacher beliefs and classroom practices through reflective practice. Language Teaching Research, 19(5), 594-610.

Farrell, T. S. C., \& Lim, P. C. P. (2005). Conceptions of grammar teaching: A case study of teachers' beliefs and classroom practices. TESL-EJ, 9(2). Retrieved from http://tesl-ej.org/ej34/a9.pdf

Fisher, P. J., Bates, A., \& Gurvitz, D. J. (2014). The complete guide to tutoring struggling readers. Mapping interventions to purpose and CCSS. New York, NY: Teachers College Press.

Fried, R. (1995). The passionate teacher: A practical guide. Boston, MA: Beacon Press.

Gambrell, L. B. (2011). Seven rules of engagement. What's most important to know about motivation to read. The Reading Teacher, 65(3), 172-178.

Gerami, M. R., \& Noordin, N. B. T. (2013). Teacher cognition in foreign language vocabulary teaching: A study of Iranian high school EFL teachers. Theory \& Practice in Language Studies, 3(9), 15-31.

Graham, S., Santos, D., \& Francis-Brophy, E. (2014). Teacher beliefs about listening in a foreign language. Teaching and Teacher Education, 40, 44-60.

Guthrie, J. T. (Ed.). (2008). Engaging adolescents in reading. Thousand Oaks, CA: Corwin Press.

Guthrie, J. T., Coddington, C. S., \& Wigfield, A. (2009). Profiles of motivation for reading among African American and Caucasian students. Journal of Literacy Research, 41, 317-353.

Guthrie, J. G., Van Meter, P., McCann, A., Wigfield, A., Bennett, L., Poundstone, C., Rice, M. E., Faibisch, F., Hunt, B., \& Mitchell, A. (1996). Growth in literacy engagement: Changes in motivations and strategies during conceptoriented reading instruction. Reading Research Quarterly, 31, 306-333.

Harste, J. C., \& Burke, C. L. (1977). A new hypothesis for reading teacher research: Both the teaching and learning of reading is theoretically based. In P. D. Pearson (Ed.), Reading: Theory, research and practice (pp. 32-40). New York, NY: National Reading Conference.

Hayes, J. (2002). Interpersonal skills at work (2nd ed.). Hove: Routledge.

Heafner, T. L., \& Spooner, M. (2008). Promoting learning in a professional development school: Helping students "get over the mountain". In I. N. Guadarrama, J. M. Ramsey, \& J. L. Nath (Eds.), University and school connections: Research studies in professional development schools (vol. 3, pp. 117-150). Charlotte, NC: Information Age Publishing. Henry, A. J. (2009). Gender differences in compulsory school pupils' L2 self-concepts: A longitudinal study. System, 37, 177-193.

Jackson, P. (1968). Life in classrooms. New York, NY: Holt, Rinehart \& Winston.

Johnson, K. E. (2009). Second language teacher education: A sociocultural perspective. New York, NY: Routledge.

Kaplan, D. S., Peck, B. M., \& Kaplan, H. B. (1997). Decomposing the academic failure-dropout relationship: A longitudinal analysis. Journal of Educational Research, 90, 331-343. 
Khan, T. J. (2016a). Motivation for reading English as a Second Language (ESL) through the use of WhatsApp among graduate students of government college township, Lahore (Pakistan). International Journal of Pure and Applied Researches, 1(2), 220-231.

Khan, T. J. (2016b). Exploration of instrumental and integrative motivation for reading English as a second language among second year pre-university students of government MAO college, Lahore (Pakistan). Open Journal of Social Sciences, 4, 69-76.

Koda, K. (2005). Insights into second language reading: A cross-linguistic approach. New York, NY: Cambridge University Press.

Kush, J. C., Marley, W. W., \& Brookhart, S. M. (2005). The temporal-interactive influence of reading on achievement and reading attitude. Educational Research and Evaluation, 11(1), 29-44.

Kuzborska, I. (2011). Links between teachers' beliefs and practices and research on reading. Reading in a Foreign Language, 23(1), 102-128.

Landing-Corretjer, G. R. (2015). The truth about homework from the students' perspective. USA: Lulu Publishing Services.

Liao, W. Y. (2009). A study of the motivation, attitudes, self-efficacy, and achievements in English learning of vocational high school students in metropolitan Taipei (Unpublished Master's dissertation). Nationl Hualien University of Education, Hualien, Taiwan.

Li, Y., \& Wang, C. (2010). An empirical study of reading self-efficacy and the use of reading strategies in the Chinese EFL context. Asian EFL Journal, 12(2), 144-162.

Lukhele, B. B. S. (2013). Exploring relationships between reading attitudes, reading ability and academic performance amongst primary teacher trainees in Swaziland. Reading \& Writing, 4(1). Retrieved from http://dx.doi.org/ 10.4102/rw.v4i1.28

Mackey, A., \& Gass, S. M. (2005). Second language research: Methodology and design. Mahwah, NJ: Lawrence Erlbaum Associates.

Maehr, M. L., \& Midgley, C. (1991). Enhancing student motivation: A schoolwide approach. Educational Psychologist, 26(3/4), 399-427.

Mante-Estacio, M. J. (2012). Dimensions of reading motivation among Filipino bilinguals. TESOL Journal, 7, 10-29.

Marshall, M. (2012). Discipline without stress, punishments or rewards: How teachers and parents promote responsibility and learning (2nd ed., revised). Los Alamitos, CA: Piper Press.

Martinez, M. E. (2010). Learning and cognition: The design of the mind. Upper Sadle River, NJ: Merrill.

McGlinn, J., \& Parrish, A. (2002). Accelerating ESL students' reading progress with accelerated reader. Reading Horizons, 42(2), 175-189.

McKenna, M. C. (2001). Development of reading attitudes. In L. Verhoeven \& C. Snow (Eds.), Literacy and motivation: Reading engagement in individuals and groups (pp. 124-144). Mahwah, NJ: Lawrence Erlbaum Associates.

McKenna, M. C., Kear, D. J., \& Ellsworth, R. A. (1995). Children's attitudes toward reading: A national survey. Reading Research Quarterly, 30, 934-955.

McKenna, M. C., \& Stahl, K. A. D. (2009). Assessment for reading instruction (2nd ed.). New York, NY: Guilford.

McKenna, M., Stratton, B., Grindler, M., \& Jenkins, S. (1995). Differential effects of whole language and traditional instruction on reading attitudes. Journal of Reading Behavior, 27, 19-44.

Merisuo-Storm, T., \& Soininen, M. (2012) Constructing a research-based program to improve primary school students' reading comprehension skills. IJCDSE, International Journal for Cross- Displinary Subjects in Education, 3(3), 755762.

Mills, N., Pajares, F., \& Herron, C. (2007). Self-efficacy of college intermediate French students: Relation to achievement and motivation. Language Learning, 57(3), 417-442.

Naseri, M., \& Zaferanieh, E. (2012). The relationship between reading self-efficacy beliefs, reading strategy use and reading comprehension level of Iranian EFL learners. World Journal of Education, 2, 64-75.

Nicholls, J. G., Miller, A. T. (1984). Reasoning about the ability of self and others: A developmental study. Child Development, 55, 1990-1999.

O'Donnell-Allen, C. (2006). The bookclub companion: Fostering strategic readers in the secondary classroom. Portsmouth, NH: Heinemann.

Olson, K. (2008). The wounded student. Educational Leadership, 65(6), 46-49.

Ordonez-Jasis, R., \& Ortis, R. W. (2006). Reading their worlds: Working with diverse families to enhance children's early literacy development. Young Children, 61, 42-48.

Orencia, M. A. R. (2006). Enhancing pupils reading comprehension and attitudes through a whole language-inspired literature-based reading program. CELEA Journal, 29(3), 3-18.

Perez, M. (2004). Personality types, motivational factors, and reading performance of high school students (Unpublished Master's dissertation). University of the Philippines, Diliman, Philippines.

Pressley, M., \& Allington, R. L. (2015). Reading instruction that works: The case for balanced teaching (4th ed.). New York, NY: The Guilford Press.

Quirk, M., Unrau, N., Ragusa, G., Rueda, R., Lim, H., Velasco, A., Fujii, K., Bowers, E., Nemerouf, A., \& Loera, G. (2010). Teacher beliefs about reading motivation and their enactment in classrooms: The development of a survey questionnaire. Reading Psychology, 31(2), 93-120. 
Richards, H. C., \& Bear, G. G. (1986). Attitudes toward school subjects of academically unpredictable elementary school children. Paper presented at the meeting of the American Educational Research Association, San Francisco, CA.

Richards, J. C., \& Rodgers, T. (2001). Approaches and methods in language teaching (2nd ed.). Cambridge: Cambridge University Press.

Richardson, V. (2003). Pre-service teachers' beliefs. In J. Raths \& A. Raths McAninch (Eds.), Teacher beliefs and classroom performance: The impact of teacher education (pp. 1-42). Greenwich, CT: Information Age Publishing.

Ro, E. (2013). A case study of extensive reading with an unmotivated L2 reader. Reading in a Foreign Language, 25(2), 213-233.

Roe, A. (2016). Students' perspectives on reading instruction and reading engagement. In K. Klette, O. K. Bergem, \& A. Roe (Eds.), Teaching and learning in lower secondary schools in the era of PISA and TIMSS (pp. 85-100). Cham: Springer.

Saito, K., \& van Poeteren, K. (2012). Pronunciation-specific adjustment strategies for intelligibility in L2 teacher talk: Results and implications of a questionnaire study. Language Awareness, 21(4), 1-17.

Sani, B. B., Chik, M. N. B. W., Nik, Y. B. A., Raslee, N. A. B. (2011). The reading motivation and reading strategies used by undergraduates in University Teknologi MARA Dungun, Terengganu. Journal of Language Teaching \& Research, 2(1), 32-39.

Sendan, F., \& Roberts, J. (1998). Orhan: A case study in the development of a student teacher's personal theories. Teachers and Teaching: Theory and Practice, 4, 229-244.

Stevens, S. (2011). Entering bookworld: How to help both boys and girls in class read alouds. Teacher as Leader, EDU $600,1-9$.

Su, M. H-M., \& Wang, J. J. (2012). A study of English self-efficacy and English reading proficiency of Taiwanese junior high school students. International Journal of Asian Social Science, 2(7), 984-998.

Ünal, E. (2010). An analysis of the reading attitudes of elementary school fourth and fifth grade students. The New Educational Review, 22(3-4), 117-127.

Urdan, T. C. \& Maehr, M. L. (1995). Beyond a two-goal theory of motivation and achievement: A case for social goals. Review of Educational Research, 65, 213-243.

van Haren, R., \& Vervoorn, J. (2012). Really teaching reading: Revisiting a MyRead strategy in a secondary English classroom. In J. Manuel \& S. Brindley (Eds.), Teenagers and reading: Literary heritages, cultural contexts and contemporary reading practices (pp. 141-160). Kent Town: Wakefield Press in association with the Australian Association for the Teaching of English.

Weathington, B. L., Cunningham, C. J. L., \& Pittenger, D. J. (2010). Research methods for the behavioral and social sciences. New York, NY: John Wiley \& Sons.

Wigfield, A. (2000). Facilitating children's reading motivation. In L. Baker, M. J. Dreher, \& J. T. Guthrie (Eds.), Engaging young readers: Promoting achievement and motivation (pp. 140-158). New York, NY: The Guilford Press.

Wigfield, A., \& Guthrie, J. T. (1997). Relations of children's motivation for reading to the amount and breadth of their reading. Journal of Educational Psychology, 89, 420-432.

Wigfield, A., \& Tonks, S. (2010). The development of motivation for reading and how it is influenced by CORI. In J. T. Guthrie, A. Wigfield, K. C. Perencevich (Eds.), Motivating reading comprehension. Concept oriented reading instruction (pp. 249-272). Mahwah, NJ: Lawrence Erlbaum Associates.

Wigfield, A., Eccles, J. S., \& Rodriguez, D. (1998). The development of children's motivation in school contexts. In. A. Iran-Nejad \& P. D. Pearson (Eds.), Review of research in education (Vol. 23, pp. 73-118). Washington, DC: American Educational Research Association.

Woolfolk, A., \& Margetts, K. (2013). Educational psychology (3rd ed.). Frenchs Forest: Pearson Australia.

Yamashita, J. (2013) Effects of extensive reading on reading attitudes in a foreign language. Reading in a Foreign Language, 25(2), 248-263.

Yang, L., \& Gao, S. (2013). Beliefs and practices of Chinese university teachers in EFL writing instruction. Language, Culture and Curriculum, 26(2), 128-145.

Yukawa, J. (2006). Co-reflection in online learning: Collaborative critical thinking as narrative. International Journal of Computer-Supported Collaborative Learning, 1(2), 203-228.

Zepeda, S. J. (2015). Job-embedded professional development: Support, collaboration, and learning in schools. New York, NY: Routledge.

Zheng, H. (2015). Teacher beliefs as a complex system: English language teachers in China. Cham: Springer International Publishing.

Zimmerman, B. J., \& Schunk, D. H. (Eds.). (2011). Handbook of self-regulation of learning and performance. New York, NY: Routledge. 